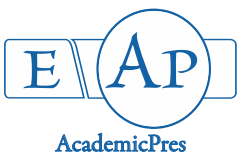

Das P et al. (2021)

Notulae Scientia Biologicae

Volume 13, Issue 4, Article number 11061

DOI: $10.15835 / \mathrm{nsb} 13411061$

Research Article

\title{
Study on the effect of $\gamma$-irradiation (Co-60) on seed germination and agronomic traits in tomato plants (Lycopersicon esculentum L.)
}

\author{
Pronabananda DAS ${ }^{1 *}$, Md. Monirul ISLAM ${ }^{1}$, Md. Humayun KABIR ${ }^{1}$, \\ Md. Monirul ISLAM ${ }^{1}$, S.A.M. Shariar ISLAM ${ }^{1}$, Md. Rafiqul ISLAM ${ }^{1}$, \\ Mustari T. JAHAN ${ }^{1}$, Prodip K. ROY ${ }^{3}$, Rathindranath HALDER ${ }^{4}$, \\ Protul K. ROY ${ }^{2}$, A.N.K. MAMUN ${ }^{1}$, Md. L. HOSSAIN ${ }^{5}$
}

\author{
'Plant Biotechnology and Genetic Engineering Division, Institute of Food and Radiation Biology, Atomic Energy Research \\ Establishment, Bangladesh Atomic Energy Commission, Dhaka, Bangladesh; daspronab12@gmail.com (corresponding author); \\ monirul.rubd@gmail.com; mithu_my@yahoo.com;monirgebcu@gmail.com; shariar.du12@gmail.com; \\ mrislam_72002@yahoo.com;mustari_baec@yahoo.com;ankmamun@yahoo.com \\ ${ }^{2}$ Molecular Radiobiology and Biodosimetry Division, Institute of Food and Radiation Biology, Atomic Energy Research \\ Establishment, Bangladesh Atomic Energy Commission, Dhaka,Bangladesh; protulroy2006@yahoo.com \\ ${ }^{3}$ University of Dhaka, Department of Microbiology,Dhaka-1000,Bangladesh;pkroyprodip@yahoo.com \\ ${ }^{4}$ Ministry of Education, Govt. Republic of Bangladesh, Bangladesh; rathindra.du@gmail.com \\ ${ }^{5}$ Institute of Tissue Banking and Biomaterial Research, Atomic Energy Research Establishment, Bangladesh Atomic Energy \\ Commission Dhaka, Bangladesh; liakat88ju@gmail.com
}

\begin{abstract}
Mutagenesis is an important technique for creating novel mutants having improved agronomic traits. In this study, $\mathrm{LD}_{50}$ was determined at $807 \mathrm{~Gy}$ depending on the germination percentage of tomato seeds irradiated with cobalt-60, using absorbed gray (Gy) dose of 50, 100, 150, 200, 250, 500, and 1000 Gy with control. $\mathrm{GR}_{30}$ and $\mathrm{GR}_{50}$ values were 214 and 502 Gy based on the regression formula on seedling length. Though $\mathrm{LD}_{50}$ is important, the dose range between $214\left(\mathrm{GR}_{30}\right)$ and $502\left(\mathrm{GR}_{50}\right)$ is more functional to get desirable mutation as the survival of the mutants is more important than germination. The variation was observed in all of the agronomical traits among the treatments. Most of the morphological traits were found better at $250 \mathrm{~Gy}$ in comparison with the control and the value decreased sharply at higher doses followed. The highest weight of single fruit was $145.33 \mathrm{~g}$ recorded at $250 \mathrm{~Gy}$ while the lowest was $70.67 \mathrm{~g}$ noted at $500 \mathrm{~Gy}$. The highest fruit yield per plant was $1270 \mathrm{gm}$ obtained at $250 \mathrm{~Gy}$ and the lowest was $800 \mathrm{gm}$ found at $500 \mathrm{~Gy}$. Shelf life was found better ( 34 days) at the 250 Gy dose level and the lowest was 6 days got in the control treatments.

Keywords: $\mathrm{BARI}$ tomato-8; $\mathrm{GR}_{50}$; irradiation; $\mathrm{LD}_{50}$; mutation breeding; shelf life

Abbreviations: M1: Mutant 1; $\mathrm{GR}_{30}$ : Growth Rate; $\mathrm{LD}_{50}$ : Lethal Dose; BARI: Bangladesh Agricultural Research Institute; CRBD: Completely Randomized Blocked Design; CV: Coefficient of Variance; ANOVA: Analysis of Variance; DMRT: Duncan's Multiple Range Test; DAP: Days after Planting; IFRB: Institute of Food and Radiation Biology
\end{abstract}




\section{Introduction}

Tomato (Lycopersicon esculentum L.) is one of the most important worldwide cultivated vegetable crops. It belongs to the Solanaceae family having a short life cycle (Dielen et al., 2001) and a simple diploid genome $(2 n=2 x=24)$ (Kulawiec et al., 2003). It is also one of the most popular crops as it is used both as a fresh and processed product. Tomato originated from Tropical America but now it is cultivated extensively all over the world including Bangladesh as it is the richest source of nutrient dietary fibers, antioxidants, and betacarotene (Hobson and Grierson, 1993; Beecher, 1998). According to FAOSTAT (2018), total tomato production in Bangladesh was about 385308.00 tonnes upon cultivation on 28130 ha land and the yield was $136878 \mathrm{hg} / \mathrm{ha}$ (FAOSTAT, 2018). But the yield of tomato productions hampered by various biotic and abiotic stresses originating from the rapidly changing adverse climatic condition along with narrow genetic diversity of the cultivated tomatoes. Besides, shelf life is an important factor in tomato after harvesting as tomato has a very short shelf life usually 2-3 weeks at ambient conditions (Ashenafi and Tura, 2018). To overcome the tailback, introgression of the wild genome may carry well but in the other case, it may rupture the genetic background of the cultivated tomato cultivars. There is another limitation to this problem is crossing incompatibility between the wild and cultivated species. Besides, various biotechnological attempts have been made by different scientists to overcome these constraints. Several attempts were made to improve tomato transformation and regeneration in Bangladesh (Sarker et al., 2009; Das et al., 2015). But the major limitations with the transformation method are dipping and infiltration which have been cited as inefficient in tomato plants (Chaudhary et al., 2019). In this regard, induced mutagenesis is one of the promising techniques to broaden the genetic diversity in the existing tomato genome pool which will help in crop improvement. This technique has been used in a variety number of crop species including rice (Yao et al., 2018), watermelon (Tian et al., 2018), and banana (Tripathi et al., 2019). Mutation breeding makes use of the possibility of altering genes by exposing seeds or other plant parts to chemical or physical mutagens (Broertjes, 1978). For the improvement of tomato, induced mutagenesis, as a breeding strategy, has been explored by different scientists (GonzalezCepero, 2005; Masuda and Ojiewo, 2006; Tomlekova, 2010). Among the physical mutagens, gamma-ray and fast neutrons are frequently applied for mutagenesis in tomatoes (Menda et al., 2004; Matsukura et al., 2007). Studies have shown that ionizing radiation like gamma-ray has a significant effect in the improvement of various agricultural traits such as reduction of post-harvest loss through suppressing sprouting and contamination, eradication of insect pests, reduction of food-borne diseases, and extensions of shelf life (Andress et al., 1994; Emovon, 1996).

The shelf life of tomatoes decreases when harvested in the latter stages but it showed better storability while harvested early. On the other hand, early harvest causes yield loss in weight (Subburamu et al., 1990). As a consequence, it is of great importance to increase the production and to improve the keeping quality of this plant for meeting the demand of consumers. By applying appropriate doses on tomato seeds to gamma irradiation, a desirable mutant could be found which would have significant importance to mankind providing sustainable production. The first step in the mutation breeding experiment is to optimize the dose level to get variability with the useful mutation. The lethal dose $50\left(\mathrm{LD}_{50}\right)$ and growth reduction $50\left(\mathrm{GR}_{50}\right)$ are the two most important factors to determine the high probability of producing effective mutations (Songsri et al., 2011). Based on these two parameters, an optimized dose range is calculated. M1 population is then cultivated and screened based on phenotypic changes to select a variation. This study was undertaken to optimize the irradiation dose level and to observe the effect of irradiation on morphological characteristics in tomato plants (M1). 


\section{Materials and Methods}

\section{Collection of seeds}

This study was carried out at the Plant Biotechnology and Genetic Engineering Division to estimate the effect of irradiation on the improvement of yield and yield attributes. Seeds of tomato, 'BARI Tomato-8', were collected from Bangladesh Agricultural Research Institute (BARI), Joydevpur, Gazipur.

\section{Irradiation of seeds}

These seeds were irradiated with different doses of gamma irradiation i.e. 50, 100, 150, 200, 250, 500, and 1000 Gy at Gamma Source Division under the Institute of Food and Radiation Biology which uses Cobalt 60 as a source of Gamma. 50 seeds were used for each treatment. These treated seeds were allowed to grow in both of laboratory and field conditions along with control to estimate the effect of irradiation on seed germination. This was done using the following formula:

Germination percentage over control $=\frac{\text { No of seeds germinated in a specific dose }}{\text { No of seeds germinated in control }} \times 100$

\section{Sterilization of seeds}

In the laboratory test, seeds were sterilized with $70 \%$ ethanol and then washed with distilled water 3-5 times. These seeds were then plated on Petri dishes containing wet blotting paper and kept in a growth cabinet with controlled temperature. In the field, 8 pots were well prepared suitable for seed germination. Water was applied when required to maintain the soil moisture. The planted seeds were checked every day starting from the first day of germination. Germination data were recorded after the $2^{\text {nd }}$ week. El-Lakany and Sziklai (1970) were followed to determine the germination criteria that the radicle had been normal and exceeded the seed length. Seedlings' height was measured with the metered rule only after the $1^{\text {st }}$ leaf had stopped growing.

\section{Determination of $L D_{50} \& G R_{50}$}

The lethal dose $\left(\mathrm{LD}_{50}\right)$ was assayed after 30 days counting the germination percentage. Growth Reduction $\left(\mathrm{GR}_{50}\right)$ was also determined using the mean seedling height affected by the irradiation which is also a very important factor to evaluate the effect of radiation on the plants. The experiment was designed to $2 \times 2$ factorial design in Completely Randomized Blocked Design (CRBD).

\section{Data collection of M1 plant}

All the morphological data i. e. plant height, number of leaves, number of branches, Internode length, number of fruits per plant, single fruit fresh weight, dry weight, fruit yield per plant, and shelf life. The shelf life was determined by keeping the fruits at room temperature from the different treatments' doses.

\section{Statistical analysis}

The data were analyzed for the estimation of variance, linear correlation, coefficient of variance $(\mathrm{CV})$ at $0.05 \%$ level by analysis of variance (ANOVA). The mean differences were adjusted with Duncan's Multiple Range Test (DMRT) using the statistical computer package program. $\mathrm{LD}_{50}$ and $\mathrm{GR}_{50}$ were determined with Curve Expert 1.4.

\section{Results}

\section{Dose optimization}

The effect of treating tomato seeds with 50,100, 150, 200, 250, 500, and 1000 Gy gamma-ray with control on the germination percentage is shown in Table 1. Germination \% over control was calculated after 7 days (7 DAP) and a general decreasing tendency (Figure 1) was observed in this case with the lowest effect 
(100) found at control seeds and highest radio-sensitivity was found 43.34 at a higher dose level $1000 \mathrm{~Gy}$ (Table 1). This lowest germination percentage revealed the injury to the treated seeds which might have prevented them from germinating well. $\mathrm{LD}_{50}$ was determined at $807 \mathrm{~Gy}$ (Figure 2).

Table 1. Effect of different doses of gamma irradiation on seed germination and seedling length after 7 DAP of BARI Tomato-08

\begin{tabular}{|c|c|c|c|c|}
\hline $\begin{array}{c}\text { Observation } \\
\text { number }\end{array}$ & $\begin{array}{c}\text { Irradiation doses } \\
(\mathrm{Gy})\end{array}$ & $\begin{array}{c}\text { Germination \% over } \\
\text { control }\end{array}$ & $\begin{array}{c}\text { Mean seedling } \\
\text { length/dose }(\mathrm{cm})\end{array}$ & $\begin{array}{c}\text { Reduction in } \\
\text { seedling } \\
\text { length }(\%)\end{array}$ \\
\hline 01 & 0 & $100 \mathrm{a}$ & $13.77 \mathrm{a}$ & - \\
\hline 02 & 50 & $91.74 \mathrm{abc}$ & $10.73 \mathrm{a}$ & 22.07 \\
\hline 03 & 100 & $88.38 \mathrm{bc}$ & $10.44 \mathrm{a}$ & 24.18 \\
\hline 04 & 150 & $85.48 \mathrm{~cd}$ & $09.70 \mathrm{ab}$ & 33.84 \\
\hline 05 & 200 & $76.34 \mathrm{de}$ & $09.11 \mathrm{ab}$ & 36.24 \\
\hline 06 & 250 & $71.33 \mathrm{ef}$ & $08.78 \mathrm{ab}$ & 49.38 \\
\hline 07 & 500 & $64.73 \mathrm{f}$ & $06.97 \mathrm{ab}$ & 81.84 \\
\hline 08 & 1000 & $43.59 \mathrm{~g}$ & $02.50 \mathrm{~b}$ & \\
\hline CV\% & & 3.86 & 27.32 & \\
\hline
\end{tabular}

In a column, the figures with a similar letter $(s)$ do not differ significantly by DMRT (Duncan's multiple range test) at $\mathrm{p}<0.05$; CV: Coefficient of variation; ${ }^{* * *}=$ significant

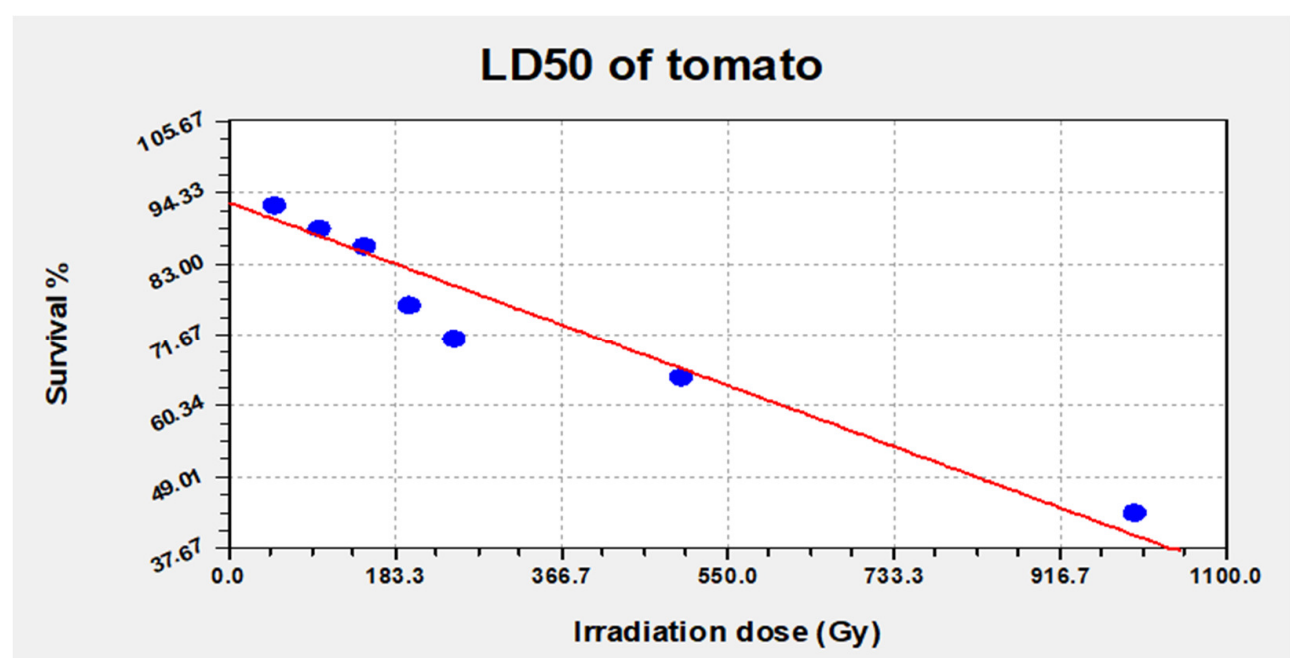

Figure 1. Determination of $\mathrm{LD}_{50}$ of BARI tomato-08 depending on the seedling's survival percentage on 7 DAP

At linear fit, $y=a+b x ; a=9.267 \& b=-5.286$; At $50 \%$ survival, LD50= 807 Gy 

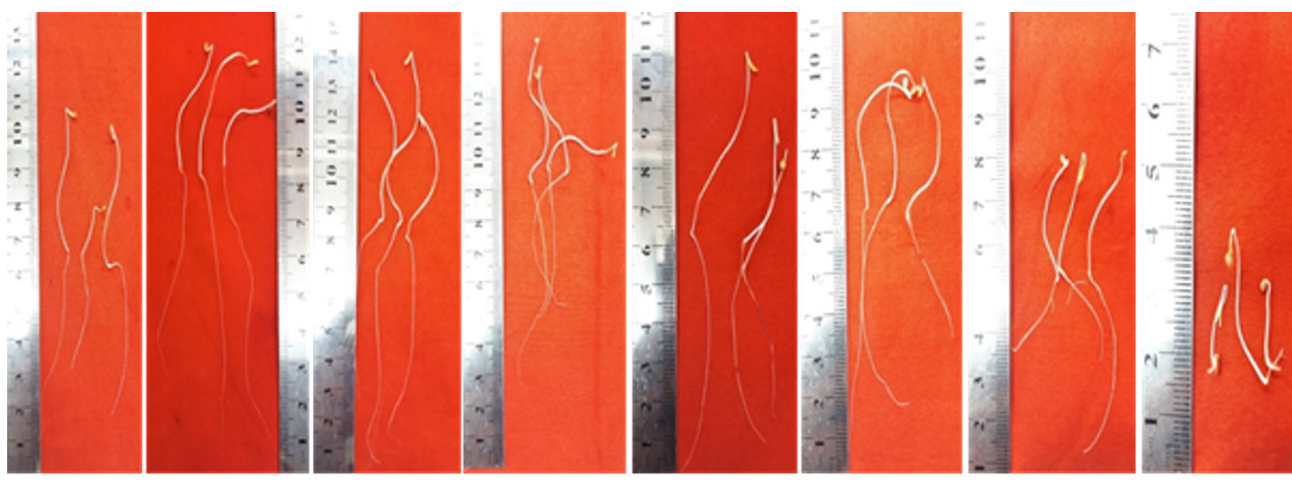

Contr. $50 \mathrm{~Gy}$

100 Gy

150 Gy

200 Gy

250 Gy

500 Gy

$1000 \mathrm{~Gy}$

Figure 2. Effect of gamma irradiation on the seeds of BARI tomato- 8 at the seedling stage

Another important criterion, growth reduction $\left(\mathrm{GR}_{50}\right)$ was also determined using the seedling height along with the dose of irradiation applied. $\mathrm{GR}_{50}$ was estimated at $509 \mathrm{~Gy}$ (Figure 3). Table 1 shows that there was a gradual decrease in length of seedlings as the dose level increased. But a sharp decrease was recorded $49.38 \%$ reduction at $500 \mathrm{~Gy}$ and $81.84 \%$ at 1000 Gy compared with the control.

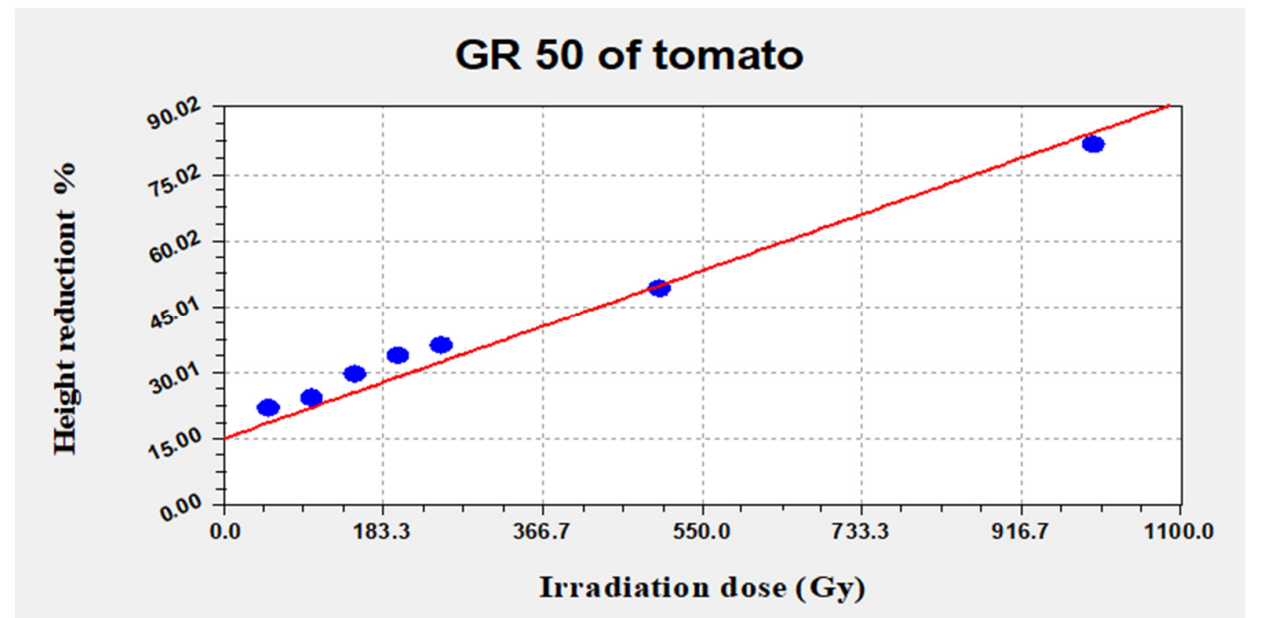

Figure 3. Estimation of seedling height reduction relating with the irradiation doses At linear fit, $y=a+b x ; a=1.512 \& b=6.940 ;$ At 50\% Growth reduction, GR50= 502Gy; At $30 \%$ growth reduction, GR30=214Gy

\section{Effect of $\gamma$-Irradiation on the morphological characters of $M 1$ plants}

All treatments with gamma irradiation were found to be lethal with doses at $1000 \mathrm{~Gy}$ or higher. So, all remaining treatments along with control plants were transplanted in the field and assessed for the various morphological characteristics related to yield e.g., plant height, number of branches per plant, number of leaves, inter-nodal length, number of nodes per plant, number of fruits per plant, single fruit weight (dry weight and fresh weight) and shelf life.

In this experiment, through data analysis, gamma-ray applications showed to have higher variability in morphological characteristics of plants without any pattern (Table 2). Invariable changes were found with different doses of treatment. But it was found that at $250 \mathrm{~Gy}$ most of the traits were better compared with the control treatment and after that all the values decreased sharply.

An observation on the data revealed that the maximum plant height of $129 \mathrm{~cm}$ was recorded at $150 \mathrm{~Gy}$ and the minimum $(83 \mathrm{~cm})$ was in treatments irradiated with $500 \mathrm{~Gy}$. The highest number of leaves (46) was 
found at 250 Gy comparing with other doses while the lowest was 30.67 at $500 \mathrm{~Gy}$. The number of branches was 11 at the dose level of $200 \& 250$ Gy. Variability was also found in the intermodal length among the treatments but lower than the control plants $(7.47 \mathrm{~cm})$. However, all the treatments showed unique characters at the traits of fruit setting pattern. But in the case of the number of fruits per plant was variable among the different doses. Average fruit weights among the irradiated treatments were statistically higher than the control plants. The highest fruit weight $(145.33 \mathrm{~g}$ ) was recorded at the doses of $250 \mathrm{~Gy}$ while the lowest $70.67 \mathrm{~g}$ was at $500 \mathrm{~Gy}$. Fruit yield was observed equal or better in the treated seeds than the control treatments except for the higher dose level of 500 Gy which had an inhibitory effect on almost all of the morphological traits.

Table 2. Effects of gamma irradiation on the morphological characteristics of M1 'BARI tomato-08' plants

\begin{tabular}{|c|c|c|c|c|c|c|c|}
\hline Treatments & $\begin{array}{l}\text { Plant height } \\
\text { (cm) }\end{array}$ & \multicolumn{2}{|c|}{$\begin{array}{l}\text { No. of compound } \\
\text { leaves plant }{ }^{-1} / \\
\text { No of leaflet } \\
\text { compound leaf }^{-1}\end{array}$} & \multicolumn{2}{|c|}{$\begin{array}{c}\text { No. of branches/ } \\
\text { plant }\end{array}$} & $\begin{array}{c}\text { No. of node/ } \\
\text { plant }\end{array}$ & $\begin{array}{l}\text { Internode length } \\
(\mathrm{cm})\end{array}$ \\
\hline 0 & $111.00 \mathrm{~b}$ & \multicolumn{2}{|c|}{$50.00 \mathrm{a} / 10.00$} & \multicolumn{2}{|c|}{$7.00 \mathrm{ab}$} & $18.00 \mathrm{ab}$ & $7.47 \mathrm{a}$ \\
\hline $50 \mathrm{~Gy}$ & $115.00 \mathrm{~b}$ & \multicolumn{2}{|c|}{$46.00 \mathrm{a} / 7.33$} & \multicolumn{2}{|c|}{$9.33 \mathrm{ab}$} & $14.00 \mathrm{bc}$ & $6.00 \mathrm{bc}$ \\
\hline $100 \mathrm{~Gy}$ & $115.33 b$ & \multicolumn{2}{|c|}{$42.33 \mathrm{ab} / 9.67$} & \multicolumn{2}{|c|}{$7.000 \mathrm{ab}$} & $18.00 \mathrm{ab}$ & $5.13 c$ \\
\hline $150 \mathrm{~Gy}$ & $129.00 \mathrm{a}$ & \multicolumn{2}{|c|}{$32.33 \mathrm{bc} / 14.33$} & \multicolumn{2}{|c|}{$6.33 \mathrm{ab}$} & $21.00 \mathrm{a}$ & $5.57 \mathrm{bc}$ \\
\hline $200 \mathrm{~Gy}$ & $112.33 \mathrm{~b}$ & \multicolumn{2}{|c|}{$34.67 \mathrm{bc} / 13.00$} & \multicolumn{2}{|c|}{$11.00 \mathrm{a}$} & $15.00 \mathrm{bc}$ & $6.80 \mathrm{ab}$ \\
\hline $250 \mathrm{~Gy}$ & $125.00 \mathrm{a}$ & \multicolumn{2}{|c|}{$46.00 \mathrm{a} / 10.33$} & \multicolumn{2}{|c|}{$11.00 \mathrm{a}$} & 16.00ab & $6.67 \mathrm{ab}$ \\
\hline $500 \mathrm{~Gy}$ & $83.00 \mathrm{c}$ & \multicolumn{2}{|c|}{$30.67 \mathrm{c} / 7.00$} & \multicolumn{2}{|c|}{$6.00 \mathrm{~b}$} & $10.33 c$ & $5.20 \mathrm{c}$ \\
\hline CV\% & 2.47 & \multicolumn{2}{|c|}{$8.92 / 26.45$} & \multicolumn{2}{|c|}{20.80} & 12.24 & 8.08 \\
\hline Treatments & $\begin{array}{c}1^{\text {st }} \text { fruit at } \\
\text { internode no. }\end{array}$ & $\begin{array}{c}\text { No. of fruit/ } \\
\text { plant }\end{array}$ & \multicolumn{2}{|c|}{$\begin{array}{l}\text { Single fruit } \\
\text { weight } \\
\text { (gm) }\end{array}$} & \% DW & $\begin{array}{c}\text { Fruit yiel } \\
\text { plant } \\
\text { (gm) }\end{array}$ & $\begin{array}{l}\text { Shelf life } \\
\text { (days) }\end{array}$ \\
\hline 0 & 1 & $12.00 \mathrm{c}$ & \multicolumn{2}{|c|}{$128.33 \mathrm{ab}$} & $5.65 b c$ & $900 \mathrm{bc}$ & $6 \mathrm{~d}$ \\
\hline $50 \mathrm{~Gy}$ & 1 & $17.00 \mathrm{ab}$ & 120 & $67 \mathrm{ab}$ & $5.52 \mathrm{~cd}$ & \multirow{2}{*}{$\begin{array}{l}900 b c \\
1000 b\end{array}$} & $7 \mathrm{~d}$ \\
\hline $100 \mathrm{~Gy}$ & 1 & $20.00 \mathrm{a}$ & \multicolumn{2}{|c|}{$138.33 \mathrm{ab}$} & $5.08 \mathrm{de}$ & & $12 \mathrm{c}$ \\
\hline $150 \mathrm{~Gy}$ & 1 & $11.00 \mathrm{c}$ & \multicolumn{2}{|c|}{$91.33 \mathrm{ab}$} & $6.07 \mathrm{~b}$ & $856 \mathrm{bc}$ & $12 \mathrm{c}$ \\
\hline $200 \mathrm{~Gy}$ & 1 & $15.00 \mathrm{bc}$ & \multicolumn{2}{|c|}{$113.00 \mathrm{ab}$} & $6.65 a$ & $1200 \mathrm{a}$ & $28 \mathrm{~b}$ \\
\hline $250 \mathrm{~Gy}$ & 1 & $17.00 \mathrm{ab}$ & & $.33 a$ & $5.20 \mathrm{cde}$ & $1270 \mathrm{a}$ & $34 a$ \\
\hline $500 \mathrm{~Gy}$ & 1 & $10.67 \mathrm{c}$ & & $67 \mathrm{~b}$ & $4.80 \mathrm{e}$ & $800 c$ & $31 \mathrm{ab}$ \\
\hline CV\% & & 11.62 & & & 3.25 & 6.07 & 8.45 \\
\hline
\end{tabular}

In a column, the figures with a similar letter $(\mathrm{s})$ do not differ significantly by DMRT (Duncan's multiple range test) at $\mathrm{p}<0.05$; CV: Coefficient of variation; ${ }^{* * *}=$ significant

The highest yield was recorded at about $1270 \mathrm{~g}$ per plant at dose 250 Gy followed by 200 Gy (1200 $\mathrm{g} / \mathrm{plant})$. In the case of higher doses 200, 250, and $500 \mathrm{~Gy}$, the shelf life was found around 28 days or more compared with the control or lower doses (6-12 days) in M1 tomato fruits (Figure 4). In the case of higher doses 200,250 , and $500 \mathrm{~Gy}$, the shelf life was found around 28 days or more compared with the control or lower doses (6-12 days) in M1tomato fruits (Figure 4). It was an important finding related to the sustainable production of tomatoes. 


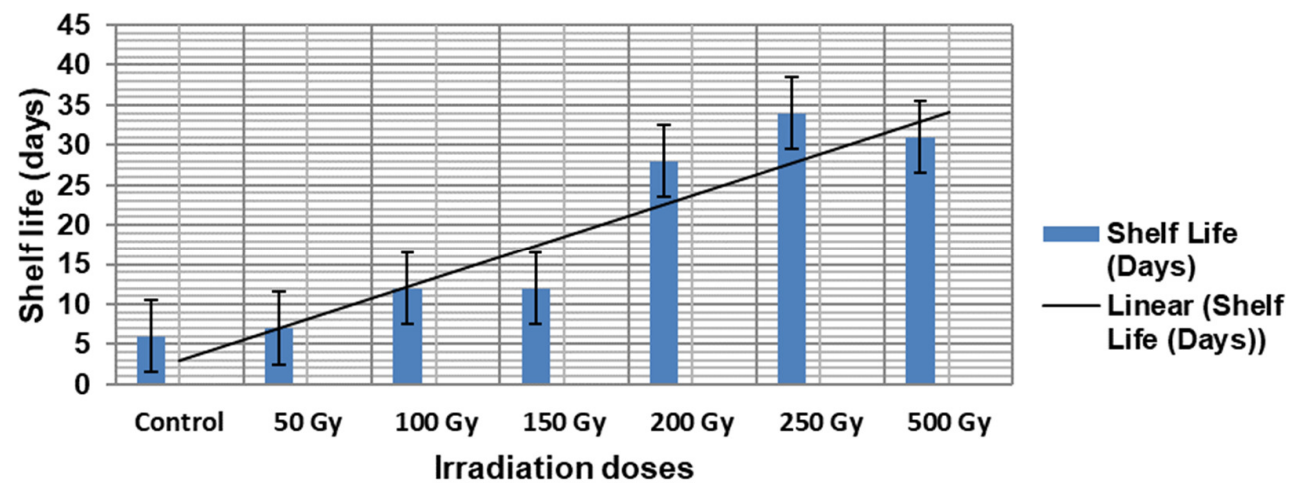

Figure 4. Effect of different doses of gamma Irradiation of BARI tomato-08 seeds on the shelf life of tomatoes

\section{Discussion}

Seeds are the most suitable material for irradiation in many mutations' induction experiments. The seed germination rate has a decreasing tendency with the increasing doses of irradiation. There are differences in mutagenic sensitivity among genotypes though this difference is much less among genotypes than species. Seeds required a higher radiation dose level than any other plant material to produce sufficient genetic mutations. The lethal dose was determined at $807 \mathrm{~Gy}$. This result was not in accordance with Brunner (1995) who found the typical dose range 200-400 Gy (Brunner, 1995). It was expected that there would be differences in the germination along with the various irradiation treatments applied as many metabolic events also occur simultaneously during this process differ in their timing, both among the various organs of the particular seeds and among seeds of different species (Hegarty, 1978; Bewley and Black, 1982; Mayer and Poljakoff-Mayber, 1989). The lethal dose 50\% value indicated that to get 50\% germination, the seeds should be treated with 807 Gy. This data is similar to the result of Norfadzrin et al. (2007). GR 50 was calculated at 509 Gy (Figure 3) which was comparable with the data of Brunner (450-600 Gy). A gradual reduction was found with the increase in dose level. Such reduction may be due to the adverse effect of irradiation in the physiological systems or growth hormone (Gunckel and Sparrow, 1961; Gaul, 1977). This significant reduction might have been caused by the plant's sensitivity to higher doses (Jamie, 2002). However, Jamie recommended that tomatoes would have an increased mutation by increasing the exposure time and the intensity of irradiation. The survived plantlets were transplanted into the experimental field to record the morphological data related to the agronomical properties, for example, height, branching, inter-nodal length (Behera et al., 2012), fruit size, shape, number, etc. The maximum height $(129 \mathrm{~cm}$ ) was noted at $150 \mathrm{~Gy}$ and the lowest was $83 \mathrm{~cm}$ in $500 \mathrm{~Gy}$. The overdominance type of gene action is the reason responsible for plant height ( Uma and Sharma, 1997; Chodhry et al., 2002). No other significant effect was found in the characteristics like number of branches/plants, number of leaves/plants, number of nodes, internodal length. Fruit weight was found maximum at $250 \mathrm{~Gy}$ and minimum at $500 \mathrm{~Gy}$. This may be due to the genetic basis of fruit development which is controlled by many genetic loci, some with a large effect and others with a small effect as mentioned (Grandillo et al., 1999; Doganlar et al., 2002; Chaim et al., 2006). Frary et al. (2000) stated that higher fruit weights might occur due to the effects of irradiation on the allele fw 2.2 (which influences fruit weight). The highest fruit yield $1270 \mathrm{gm} / \mathrm{plant}$ was recorded at $250 \mathrm{~Gy}$ followed by $1200 \mathrm{gm} / \mathrm{plant}$ at $200 \mathrm{~Gy}$ and the lowest $800 \mathrm{gm} / \mathrm{plant}$ was noticed at $500 \mathrm{~Gy}$. Different biotechnological approaches have been applied that delay the ripening approaches of tomatoes by modifying metabolic pathways through genetic engineering ( Smith et al., 1988; Matas et al., 2009; Meli et al., 2010). However, there is a concern over the use of bioengineering of crops due to food and environmental safety-related questions (Boyazoglu, 2002; Qaim, 2009). 
The shelf life of tomato, the most important factor, was found better from the treatments with the increase of irradiation doses applied on the seeds. At room temperature, maximum shelf life was got at $250 \mathrm{~Gy}$ with 34 days. The study showed that the shelf life of tomatoes ranged from 4.00-12.00 days at room temperatures collected in half ripen condition while it is 2.00-8.80 day when collected in full ripening stage (Akand et al., 2015). It was an important finding related to the sustainable production of tomatoes.

\section{Conclusions}

In this study, the effective dose level for irradiation was estimated and the consequences of it were observed on the morphological characteristics of M1 plantlets. It was found that as the doses were increased, the germination percentage and seedling height decreased gradually. $\mathrm{LD}_{50}$ was determined at $807 \mathrm{~Gy}$ though it is recommended that the dose level should be in the range of 214 to 502 to get effective mutation which was determined by the estimation of $\mathrm{GR}_{30}$ and $\mathrm{GR}_{50}$. From the investigation of the M1 population of tomatoes, 250 Gy showed the increased value in most of the traits while 500 Gy showed decreasing trends. Thus, this study it might be recommended to be useful for the future breeding program.

\section{Authors' Contributions}

Das $P$, carried out the study design, literature citing, creation of figures and tables, and manuscript writing. MH Kabir, MM Islam helped to conduct literature citing, table and figure formation, and manuscript writing. SAM.S Islam, MR Islam, MT Jahan contributed to manuscript reading and literature citing. RN Halder and PK Roy participated in helping edit, revise and approve the final manuscript. ANK Mamun supervised the writing of the manuscript and revised it critically for important intellectual content. All authors read and approved the final manuscript.

\section{Acknowledgements}

I would like to express my gratitude to Bangladesh Agricultural Research Institute for providing me seeds of 'BARI tomato-08' and Gamma Source Division for irradiating the seeds sample. I also want to thank to all co-authors and other related personnel who helped in every part of the research like planning, methodologies, data collection and manuscript writing and reviewing.

\section{Conflict of Interests}

The authors declare that there are no conflicts of interest related to this article.

\section{References}

Akand MH, Mazed HEMK, Pulok MAI, Chowdhury MSN, Moonmoon JF (2015). Effect of organic manures on assessment of shelf life of tomato varieties (Lycopersicon esculentum Mill.). International Journal of Applied Research 1(5):94-97.

Andress EL, Delaplane KS, Schuler GA (1994). Food irradiation. Institute of Food and Agricultural Sciences University of Florida, USA. 
Ashenafi H, Tura S (2018). Shelf life and quality of tomato (Lycopersicon esculentum Mill.) fruits as affected by different packaging materials. African Journal of Food Science 12:21-27. https://doi.org/10.5897/AJFS2017.1568

Beecher GR (1998). Nutrient content of tomatoes and tomato products. Proceedings of the Society for Experimental Biology and Medicine 218:98-100. https://doi.org/10.3181/00379727-218-44282a

Behera M, Panigrahi J, Mishra, RR, Rath SP (2012). Analysis of EMS induced in vitro mutants of Asteracantha longifolia (L.) Nees using RAPD markers. Indian Journal of Biotechnology 11:39-47.

Bewley JD, Black M (1982). Physiology and biochemistry of seeds. Springer-Verlag, Berlin, pp 20:97-97.

Boyazoglu J (2002). Point of view on GM organisms and traditional products - genuineness or innovation? Livestock Production Science 74(3):287-290.

Broertjes C (1978). Application of mutation breeding methods in the improvement of vegetatively propagated crops: an interpretative literature review. Elsevier Scientific Publishing Company, Amsterdam, Netherlands.

Brunner H (1995). Radiation induced mutations for plant selection. Applied Radiation and Isotopes 46:589-594. https://doi.org/10.1016/0969-8043(95)00096-8

Chaim AB, Borovsky Y, Rao G, Gur A, Zamir D, Paran I (2006). Comparative QTL mapping of fruit size and shape in tomato and pepper. Israel Journal of Plant Sciences 54:191-203.

Chaudhary J, Alisha A, Bhatt V, Chandanshive S, Kumar N, Sonah H, ... Shivaraj SMS (2019). Mutation breeding in tomato: Advances, applicability and challenges. Plants 8(5):128. https://doi.org/10.3390/plants8050128

Chodhry M, Ambreen A, Khaliq I (2002). Genetic control of some polygenic traits in Aestivum species. Asian Journal of Plant Sciences 1:235-237. https://doi.org/10.3923/ajps.2002.235.237

Das P, Ansari A, Islam MN, Sarker RH (2015). Genetic transformation of a local tomato (Solanum lycopersicum L.) variety of Bangladesh. Plant Tissue Culture and Biotechnology 25:87-97. https://doi.org/10.3329/ptcb.v25i1.24128

Dielen V, Lecouvet V, Dupont S, Kinet JM (2001). In vitro control of floral transition in tomato (Lycopersicon esculentum Mill.), the model for autonomously flowering plants, using the late flowering uniflora mutant. Journal of Experimental Botany 52:715-723. https://doi.org/10.1093/jexbot/52.357.715

Doganlar S, Frary A, Daunay MC, Leste RN, Tanksley SD (2002). Conservation of gene function in the Solanaceae as revealed by comparative mapping of domestication traits in eggplant. Genetics 161:1713-1726. https://doi.org/10.1093/genetics/161.4.1713

El-Lakany MH, Sziklai O (1970). Effects of gamma-irradiation on some Western conifers. Radiation Botany 10:411-420. https://doi.org/10.1016/S0033-7560(70)80003-5

Emovon EU (1996). Keynote Address: Symposium on Irradiation for National Development. Abuja, Nigeria

FAOSTAT (2018). Retrieved from http://www.fao.org/faostat/es/\#compare

Gaul H (1977). Mutagen effects in the first generation after seed treatment. Manual on Mutation Breeding Technical Reports Series 119:87-98. Vienna, Austria.

Gonzalez C, Mukandama JP, Fuentes JL, Mansoor MA (2005). Induction of drought tolerance in tomato using 60Co gamma ray irradiation. Mutation Breeding Newsletter and Reviews 9-10.

Grandillo S, Ku HM, Tanksley SD (1999). Identifying the loci responsible for natural variation in fruit size and shape in tomato. Theoretical and Applied Genetics 99:978-987. https://doi.org/10.1007/s001220051405

Gunckel JK, Sparrow AH (1961). Ionizing radiations: biochemical, physiological and morphological aspects of their effects on plants. Encyclopedia of Plant Physiology 16:555-611.

Hegarty TW (1978). The physiology of seed hydration and dehydration, and the relation between water stress and the control of germination: a review. Plant, Cell and Environment 1:101-119. https://doi.org/10.1111/j.1365 3040.1978.tb00752.x

Hobson G, Grierson D(1993). Tomato. In: Seymour GB, Taylor JE, Tucker GA (Eds). Biochemistry of Fruit Ripening. Springer, Dordrecht, pp 405-442.

Jamie H (2002). Induced mutations: increasing agricultural quality and yield of tomato. Athena High Sch. Sci. Res. Program, Greece, pp 132-145.

Kulawiec M, Tagashira N, Plader W, Bartoszewski G, Kuć D, Śniezko R, Malepszy S (2003). Chromosome number variation in somatic hybrids between transgenic tomato (Lycopersicon esculentum) and Solanum lycopersicoides. Journal of Applied Genetics 44:431-447.

Masuda MO, Ojiewo CO (2006). Induced mutagensis as a breeding strategy for improvement of Solanaceous vegetables. Recent Fruit and Potentiality of Mutation Breeding, pp 47-60. 
Matas AJ, Gapper NE, Chung M, Giovannoni JJ, Rose JKC (2009). Biology and genetic engineering of fruit maturation for enhanced quality and shelf-life. Current Opinion in Biotechnology 20:197-203. https://doi.org/10.1016/j.copbio.2009.02.015

Matsukura C, Yamaguchi I, Inamura M, Ban Y, Kobayashi Y, Yin YG, ... Nishimur S (2007). Generation of gamma irradiation-induced mutant lines of the miniature tomato (Solanum lycopersicum L.) cultivar "Micro-Tom." Plant Biotechnology 24:39-44.

Mayer AM, Poljakoff-Mayber A (1989). The Germination of Seeds. 4th Ed. Pergamon Press, Oxford.

Meli VS, Ghosh S, Prabha TN, Chakraborty N, Chakraborty S, Datta A (2010). Enhancement of fruit shelf life by suppressing N -glycan processing enzymes. Proceedings of the National Academy of Sciences 107:2413-2418. https://doi.org/10.1073/pnas.0909329107

Menda N, Semel Y, Peled D, Eshed Y, Zamir D (2004). In silico screening of a saturated mutation library of tomato. The Plant Journal 38:861-872. https://doi.org/10.1111/j.1365-313X.2004.02088.X

Norfadzrin F, Ahmed OH, Shaharudin S, Abdul Rahman D (2007). A preliminary study on gamma radiosensitivity of tomato (Lycopersicon esculentum) and okra (Abelmoschus esculentus). International Journal of Agricultural Research 2(7):620-625. https://doi.org/10.3923/ijar.2007.620.625

Qaim M (2009). The economics of genetically modified crops. Annual Review of Resource Economics 1:665-694. https://doi.org/10.1146/annurev.resource.050708.144203

Sarker RH, Islam K, Hoque MI (2009). In vitro regeneration and Agrobacterium-mediated genetic transformation of tomato (Lycopersicon esculentum Mill.). Plant Tissue Culture and Biotechnology 19:101-111. https://doi.org/10.3329/ptcb.v19i1.5004

Smith C, Watson C, Ray J, Bird C, Morris P, Schuch W, Grierson D (1988). Antisense RNA inhibition of polygalacturonase gene-expression in transgenic tomatoes. Nature 334:724-726. https://doi.org/10.1038/334724aO

Songsri P, Surinam B, Sanitchon J, Srisawangwong S, Kesmala T (2011). Effects of gamma radiation on germination and growth characteristics of physic nut (Jatropha curcas L.). Journal of Biological Sciences 11:268-274. https://doi.org/10.3923/jbs.2011.268.274

Subburamu K, Singaravelu M, Nazar A, Irulappan I (1990). Effect of stage of harvest in tomato cultivars in improving the shelf life and fruit quality. South Indian Horticulture 38:199-203.

Tian S, Jiang L, Cui X, Zhang J, Guo S, Li M, ... Xu Y (2018). Engineering herbicide-resistant watermelon variety through CRISPR/Cas9-mediated base-editing. Plant Cell Reports 37:1353-1356. https://doi.org/10.1007/s00299-0182299-0

Tomlekova (2010). Induced mutagenesis for crop improvement in Bulgaria. Plant Mutation Reports 2:4-27.

Tripathi JN, Ntui VO, Ron M, Muiruri SK, Britt A, Tripathi L (2019). CRISPR/Cas9 editing of endogenous banana streak virus in the B genome of Musa spp. overcomes a major challenge in banana breeding. Communications Biology 2:1-11. https://doi.org/10.1038/s42003-019-0288-7

Uma M, Sharma SN (1997). Genetics of yield determining factors in spring wheat over environments. Indian Journal of Genetics and Plant Breeding 57:235-237.

Yao L, Zhang Y, Liu C, Liu Y, Wang Y, Liang D, Liu J, Sahoo G, Kelliher T (2018). OsMATL mutation induces haploid seed formation in indica rice. Nature Plants 4:530-553. https://doi.org/10.1038/s41477-018-0193-y
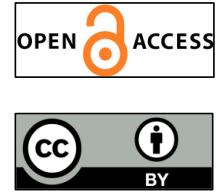

The journal offers free, immediate, and unrestricted access to peer-reviewed research and scholarly work. Users are allowed to read, download, copy, distribute, print, search, or link to the full texts of the articles, or use them for any other lawful purpose, without asking prior permission from the publisher or the author.

License - Articles published in Notulae Scientia Biologicae are Open-Access, distributed under the terms and conditions of the Creative Commons Attribution (CC BY 4.0) License.

(C) Articles by the authors; SHST, Cluj-Napoca, Romania. The journal allows the author(s) to hold the copyright/to retain publishing rights without restriction. 